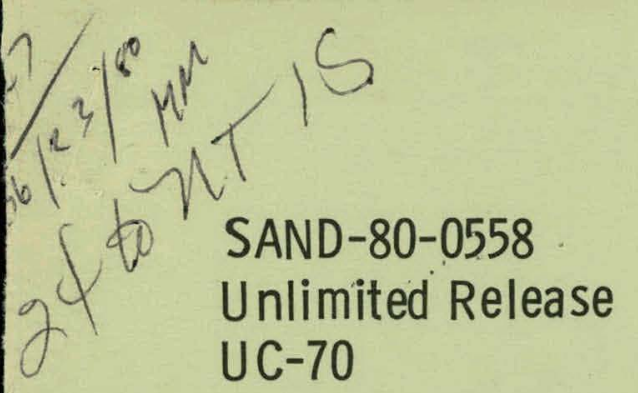

ANALYSIS OF STEADY STATE CREEP OF SOUTHEASTERN NEW MEXICO BEDDED SALT

W. Herrmann, W. R. Wawersik, H. S. Lauson

Prepared by Sandia Laboratories, Albuquerque, New Mexico 87115

and Livermore. California 94550 for the United States Department of

Energy under Contract AT (29-1)-789

Printed March 1980 


\section{DISCLAIMER}

This report was prepared as an account of work sponsored by an agency of the United States Government. Neither the United States Government nor any agency Thereof, nor any of their employees, makes any warranty, express or implied, or assumes any legal liability or responsibility for the accuracy, completeness, or usefulness of any information, apparatus, product, or process disclosed, or represents that its use would not infringe privately owned rights. Reference herein to any specific commercial product, process, or service by trade name, trademark, manufacturer, or otherwise does not necessarily constitute or imply its endorsement, recommendation, or favoring by the United States Government or any agency thereof. The views and opinions of authors expressed herein do not necessarily state or reflect those of the United States Government or any agency thereof. 


\section{DISCLAIMER}

Portions of this document may be illegible in electronic image products. Images are produced from the best available original document. 
Issued by Sandia Laboratories, operated for the United States Department of Energy by Sandia Corporation.

\section{NOTICE}

This report was prepared as an account of work sponsored by the United States Government. Neither the United States nor the Department of Energy, nor any of their employees, nor any of their contractors, subcontractors, or their employees, makes any warranty, express or implied, or assumes any legal liability or responsibility for the accuracy, completeness or usefulness of any information, apparatus, product or process disclosed, or represents that its use would not infringe privately owned rights.

Printed in the United Staties of America Available from

National Technical Information Service U. S. Department of Commerce 5285 Port Royal Road Springfield, VA 22161 Price: Printed Copy $\$$ t.00; Microfiche $\$ 4.50$ 5,0 


\author{
SAND -80-0558 \\ Unlimited Release \\ Printed March 1980
}

\title{
ANALYSIS OF STEADY STATE CREEP \\ OF SOUTHEASTERN NEW MEXICO BEDDED SALT ${ }^{*}$
}

W. Herrmann

Solid Dynamics Department 5530

W. R. Wawersik

Geomechanics Division 5532

H. S. Lauson

Computational Physics \& Mechanics Division I 5531

Sandia National Laboratories

Albuquerque, New Mexico 87185

\begin{abstract}
Steady state creep rates have been obtained from a large suite of existing experimental creep data relating to bedded rock salt from the Salado formation of S.E. New Mexico. Experimental conditions covered an intermediate temperature range from $22^{\circ} \mathrm{C}$ to $200^{\circ} \mathrm{C}$, and shear stresses from $1000 \mathrm{psi}$ ( $7 \mathrm{MPa}$ ) to 6000 psi ( $31 \mathrm{MPa}$ ). An expression, based on a single diffusion controlled dislocation climb mechanism, has been found to fit the observed dependence $n f$ steady state creep rate on shear stress and temperature, yielding an activation energy of $12 \mathrm{kcal} / \mathrm{mole}$ ( $50 \mathrm{~kJ} / \mathrm{mole}$ ) and a stress exponent of 4.9 . Multiple regression analysis revealed a dependence on stratigraphy, but no statistically significant dependence on pressure of specimen size. No consistent dilatancy or compaction associated with steady state creep was found, although some individual specimens dilated or compacted during creep. The steady state creep data were found to agree very well with creep data for both bedide and dome salt from a variety of other locations.
\end{abstract}

*This article sponsored by the U. S. Department of Energy, Office of Nuclear Waste Management under Contract DE-AC04-76-DP00789. 


\section{Table of Contents}

1. Introduction. . . . . . . . . . . . . . . 5

2. Analysis of Steady State Creep. . . . . . . . . . . 9

3. Comparison with Other Data." . . . . . . . . . . 15

4. History Effects... . . . . . . . . . . . . 17

5. Conclusions . . . . . . . . . . . . . . . . . . . . . 19

References. . . . . . . . . . . . . . 23

Tables. . . . . . . . . . . . . . 25

Figures. . . . . . . . . . . . . . . . . 33 


\section{Introduction}

An analysis has been reported ${ }^{l}$ of creep tests performed by Wawersik and Hannum, ${ }^{2}$ Hansen, ${ }^{3}$ and Hansen and Mellegard ${ }^{4,5}$ on samples of bedded rock salt from the Salado formation in the Waste Isolation Pilot Plant study area near Carlsbad, New Mexico. Individual creep tests were fitted to both exponential and logarithmic transient creep laws. The analysis provided, among other things, consistent estimates of steady-state creep rates. In this report, an analysis is presented of the dependence of steady-state creep rate on shear stress and temperature, as well as a variety of other experimental variables.

The rock salt was medium grained ( 1 to io $\mathrm{mm}$ ) to coarse grained ( 10 to $20 \mathrm{~mm}$ ) consisting of 90 to 97 modal percent halite, the remainder being polyhalite, anhydrite and small amounts of clay and silt. Geologic characterization of the salt has been summarized by Powers et al. 6 Further petrologic details have been described by Callender and Ingwell. 7

Creep tests were performed in specially designed triaxial test machines with instrumentation which allowed determination of average axial and transverse strains of the specimens. 8,9 Some tests were performed at Sandia Laboratories, Albuquerque, using large 4 in. (100 mm) diameter specimens. 2 Others were performed at RE/SPEC Inc. using smaller $2 \mathrm{in.}$ ( $50 \mathrm{~mm}$ ) diameter. specimens. 3-5 $^{-5}$ specific specimen preparation and test procedures have been described in the original references. ${ }^{2-5}$ Test specimens were machined from core retrieved from two holes (AEC \#7 and ERDA \#9), and from two different nominal depths (about $2000 \mathrm{ft}$. and $2600 \mathrm{ft.}$ ). Petrographic observations suggested mineralogical differences in the salt from these two depths which might be expected to result in differences in mochnonical behavior. 7 
In a number of cases, the same specimen was tested successively under different conditions. A creep test was conducted at one shear stress, temperature and confining stress until steady-state creep was approached. Either the shear stress or temperature was then increased and a new test initiated. Successive tests of this type are given a common test number, but successive test stage numbers in order to identify theịr relationship. In two cases, later stages were conducted at a lower shear stress (but identical temperature and confining stress) than the immediately preceding stage in order to investigate creep when the stress is dropped.

Tests covered a range of principal stress differences from 1000 to $6000 \mathrm{psi}\left(7\right.$ to $4 \mathrm{I} \mathrm{MPa}$ ), temperatures from $22^{\circ} \mathrm{C}$ to $200^{\circ} \mathrm{C}$, and confining stresses from 0 to 3000 psi ( 0 to $21 \mathrm{MPa}$ ). A test matrix of temperature, confining stress, shear stress and test stage has been given previously. ${ }^{1}$

In order to deduce steady-state creep rates from the experimental data, strain-time records for each individual test had been fitted ${ }^{l}$ to both exponential and logarithmic creep laws equivalent to the forms

$$
e=e_{0}+\dot{e}_{s} t+e_{s}\left\{1-\exp \left(-\xi_{t}\right)\right\}
$$

and

$$
e=e_{0}+\dot{e}_{s} t+e_{0} \ln (1+\eta t)
$$

where $\dot{e}_{s}$ is the steady-state creep rate and $e_{o}, e_{a}$ or $e_{c}$ and $\eta$ are constants for a given test at constant shear stress and temperature. Steady-state creep rates obtained by means of the two fits agreed quite well for most experiments. Only data relating to steady state creep for each test are 
considered here. The relevant data are reproduced in Tables 1 and 2 which list the test file ID, test number and stage, the drill hole number and depth of core ( $f t$ ) from which the specimen was cut, the specimen size (ins) temperature $\mathrm{T}\left({ }^{\circ} \mathrm{C}\right)$, shear stress (principal stress difference) $T$, confining stress $\sigma_{3}$ and hydrostatic pressure $p$ (psi), together with the steady state axial crepp rate $\dot{e}_{S_{1}}$ and transverse creep rate $\dot{e}_{S_{3}}(/ \mathrm{sec})$ and their standard errors. Complete tabulations of fitting parameters are available in the report of the previous analysis. ${ }^{l}$ 


\section{PAGES 9 to 10 WERE INTENTIONALLY LEFT BLANK}


two tests which were questionable.*

It was found that the only statistically significant coefficient, besides $a, n$ and $Q$, was $\alpha_{3}$, that is $A$ is dependent on level but there is no statistically significant dependence of $\mathrm{n}$ and $\mathrm{Q}$ on level. Moreover, there is no statistically significant dependence of $A, n$ and $Q$ on pressure, drill hole or specimen size and laboratory in which the tests were performed. Results are given in Table 3, which also shows standard errors of the fitting parameters, standard deviation of the fit to (6) and the coefficient of determination $R^{2}$. It can be seen that, loosely speaking, more than 93\% of the behavior is captured by the single expression (3) with values of the parameters given in Table 3 .

In order to illustrate the quality of the fit, the secondary creep rate for each experiment was first scaled to nominal conditions and upper level using (3) and the parameters given in Table 3. Scaled creep rates were then plotted in Figs. 1 and 2, for comparison with the solid lines representing the fit. It is readily seen that the scatter in the data. embrace about one decade in strain rate. Within this scatter, the single creep expression (3) appears to be quite adequate to describe the data, as shown by the multiple regression analysis. In particular, there is no evidence of a transition to a different activation energy $Q$ at temperatures up to $200^{\circ} \mathrm{C}$, or a different stress dependence at high stresses, within the range embraced by the data, as had been suggested previously

\footnotetext{
* Load drop tests which were omitted carried file numbers CA 106 and CA 113. Questionable tests which were omitted were RS 5502B which experienced a large stress drop early in the test, resulting in an anomalous strain history, and RS 6204. which was surmised to undergo cracking during creep.
} 
by Munson ${ }^{13,14}$ on the basis of an analysis of a subset of the present data together with data from other experimenters using salt from other sources. An identical analysis ${ }^{*}$ was performed using secondary creep rates deduced by the use of the logarithmic creep law (2) together with the definition of shear strain rate (7). Results were qualitatively similar, the resulting data also being given in Table 3 . The values of $A, n$ and Q for the two analyses are seen to agree within their standard errors. This was taken as evidence of the insensitivity of the secondary creep rates to the transient creep model.

Two analyses were also performed using steady state creep rates deduced from the two creep laws respectively, but using the definition of shear strain rate (8). Transverse strain data were missing for a number of tests, including all those at zero confining stress. In addition, some fits to the transverse strain histories provided negative secondary creep rates, which were deleted from these analyses. Consequently, the data sample was considerably reduced. To see if the use of ( 8 ) would improve the fit, the previous two analyses using (7) were also repeated with the smaller data samples. For sleady state sreep ratco dcducod from both creep laws the analyses using (7) and (8) resulted in coefficients $A$, $n$ and $Q$ which corresponded within their standard errors, with similar standard deviations. Consequently, it was concluded that the use of (8) did not improve the fit significantly.

\footnotetext{
* RS 7901A, for which $\dot{e}_{1 s}<0$, was deleted in this analyses in addition to CA 106, CA 113, RS 5502B and RS 6204.
} 
The pressure dependence, or rather lack thereof, can be illustrated by plots of scaled secondary creep rates versus confining stress for each nominal shear stress and temperature state for which several tests were available. These plots are shown in Fig. 3. While a slight decrease in . secondary creep rate with increase in pressure might be discerned in these plots, the scatter is such that the trend cannot be considered statistically significant, as indeed the multiple regression analyses have indicated.

Related to a pressure effect is the question of a volume change during creep. Initial loading of the specimen in a number of tests appeared to introduce a slight initial volume change. The volume change associated with secondary creep can be conveniently isolated from this and other spurious effects by defining the quantity

$$
\eta_{\mathrm{s}}=\frac{\dot{\varphi}_{s}}{\dot{\varphi}_{s}}
$$

where $\dot{Y}_{s}$ is the shear strain rate given by (4) and $\dot{\varphi}_{s}$ 1s the dilatation rate given by

$$
\dot{\varphi}_{s}=\dot{e}_{1 s}+2 \dot{e}_{3 s}
$$

Scaled values of secondary creep rates were used to calculate $\eta_{\mathbf{g}}$ for each test for which transverse strain fits were available. Some plots of $\mathrm{r}_{\mathrm{s}}$ versus shear stress at different constant temperatures are shown in Fig. 4. Except for a few tests, which showed relative large amounts of dilation $(\eta>0)$ or compaction $(\eta<0)$, most tests showed a volume strain rate less than about $20 \%$ of the shear strain rate, with many tests exhibiting much smaller percentages. There does seem to be a slight tendency for tests at luw curflinling stress to dilate, while those at high confining stress 
tend to compact, this tendency disappearing as the shear stress and temperature increase. In any case, the average value of $\eta_{a}$ for all tests does not differ significantly from zero, with the scatter distributed fairly evenly about zero at all shear stresses and temperatures. 


\section{Comparison With Other Data}

There have been several studies of the creep of polycrystalline salt from other sources, which can be compared with the present data. A number of data are available for salt from the Tatum dome, Mississippi. 15,16 These data include both uniaxial compression and triaxial extension data taken at two temperatures, $23^{\circ} \mathrm{C}$ and $66^{\circ} \mathrm{C}$. Steady-state creep rates are shown plotted versus shear stress in Fig. 5. Solid lines represent (3) with coefficients from Table 3 (Exponential Creep). While the scatter in the data is quite large, the data are in fair agreement with the present fit. Some of the data ${ }^{16}$ are plotted versus temperature in Fig. 6. The data have been scaled to nominal shear stresses, using (3) and coefficients from Table 3, in order to compare with the present fit. The agreement is again fair, in view of the scatter.

Triaxial creep data are available for rock salt from the Grand Saline and Hockley mines, Texas. ${ }^{17}$ The tests were conducted at $32^{\circ} \mathrm{C}$. For convenience in plotting, they were scaled to $23^{\circ} \mathrm{C}$ using (3) and coefficients from Table 3, and are also shown in Fig. 5 where they are seen to be in excellent agreement with the present fit.

A few data points have been obtained in both triaxial compression and triaxial extension using salt from the West Hackberry dome, Louisiana.. The data were taken at two temperatures $\left(22^{\circ} \mathrm{C}\right.$ and $\left.60^{\circ} \mathrm{C}\right)$ at a nominal shear stress of 3000 psi. These data were scaled, using (3) and Table 3, to a nominal shear stress of 3125 psi, and are plotted in Fig. 6, where they are seen to be in excellent agreement with the present fit.

An extensive study ${ }^{19}$ of the creep of pure synthetic polycrystalline halite included a number nt tiests within the range of slued slresses and 
temperatures of interest in this work. The relevant data are shown in Fig. 7 and 8 . The latter have been scaled using (.3) and Table 3. The agreement is again quite reasonable.

Finally, creep data are available for salt from the Asse anticline, West Germany. 20 The original data were unavailable, but they were fitted to (3). Reported values of the coefficients are

$$
\begin{aligned}
& A=9.27 \mathrm{E}+14 \quad / \mathrm{sec} \\
& 11=5.0 \\
& Q=12.9 \mathrm{kcal} / \mathrm{mole}(54.0 \mathrm{~kJ} / \mathrm{mole})
\end{aligned}
$$

which may be compared with values in Table 3 . The reported values of $A$ and $Q$ are in quite good agreement with the present data.

It is surprising that data from diverse sources agree with the present data within the order of magnitude or so scatter common to tests of this type. In particular, the various data appear to agree quite well with regard to the stress exponent $n$. Several of the data sets, taken by themselves, might indicate widely different values of the activation energy Q. However, this is probably due to the small number of data in these sets, together with a small temperature range and relatively large scatter. When plotted with the present data, the agreement is good. The general agreement of results for uniaxial compression, triaxial compression and triaxial extension further corraborates the lack of a pressure effect on steady stale lreep.

* Note that the value given here refers to $\dot{Y}_{B}$ which is related to the axial strain rate by (5). 


\section{History Effects}

A limited examination of the effects of history is possible. It has been noted that a number of tests were performed on specimens which had been tested previously at a lower stress or temperature. In one case, the same specimen was tested three times at successively higher stresses. The test sequences on different specimens can be deduced from the test and stage numbers in Tables 1 and 2 .

The test matrix was such that a number of pairs of tests may be identified, one of which was loaded directly to a given shear stress and temperature, while the other was loaded to the same shear stress and temperature after a prior stage at either a lower stress or temperature. An examination of the data, together with plots in Figs. 1 and 2 , reveals no effect of test stage on steady-state creep rate, within the scatter in the data at least for the histories represented in these tests. This suggests that steady-state creep rates may be unaffected by prior stress or temperature histories, providing that the stress and temperature increase monotonically.

Two tests were conducted on specimens which had been tested at a higher level of shear stress in a prior stage. ${ }^{*}$ The strain-time records for these two tests differed qualitatively from the others, in that they exhibited virtually no decelerating creep over the time of the tests. The strain-time records for these tests were nevertheless fitted to (1). Results are shown in Table 4. The values of $\dot{e}_{s}$ for tests CA 106 and CA 113 may be compared directly with those for tests CA 104 and CA 111 which were

* Theoc tecte corricd file numbers $\mathrm{CA}$ lo6 and $\mathrm{CA} 113$. 
performed on the same specimens in prior stages at the same stresses and temperatures respectively, but with prior monotonic loading histories. The load drop tests CA 106 and CA 113 exhibit values of $\dot{e}_{B}$ more than an order of magnitude less than CA 104 and CA 111 respectively. These observations are in accord with experience in the creep of metals.

It has been suggested that recovery, which dominates early creep in load drop tests, may require much longer times or involve much larger total strain accumulations than those experienced in CA 106 and CA 113. Little. further can be said about. the results of these two tests, but it is clear that the present data for monotoric loading must be used with extreme caution for stress histories involving stress reversals. No information is available regarding creep under decreasing temperature histories, but a similar phenomenon may be expected. 


\section{Conclusions}

An analysis has been performed of available data relating to the creep of bedded rock salt from the WIPP study area near Carlsbad, New Mexico. Usable data were obtained from 64 separate tests on 44 different samples taken from two drill holes and two levels representing different geologic strata. Tests were conducted in two laboratories on samples of two different sizes in a range of temperatures from $22^{\circ} \mathrm{C}$ to $200^{\circ} \mathrm{C}$, shear stresses (stress differences) from 1000 to $6000 \mathrm{psi}$ ( 7 to $41 \mathrm{MPa}$ ), and confining stresses from 0 to 3000 psi ( 0 to $20 \mathrm{MPa}$ ). The data were sufficient, albeit minimal, to allow statistical analysis.

The bulk of the data related to transient creep. Steady-state creep rates were deduced by making least squares fits to the data for each experiment, conducted at constant temperature, shear stress and confining stress, using both exponential and logarithmic transient creep models. 1 'I'he resulting steady-state creep rates were then fitted to Weertman's expression to obtain the dependence on temperature and shear stress, and to explore the sensitivity of the results to confining stress, geologic level, drill hole location, specimen size and laboratory at which the tests were performed. Results of the two analyses using the two primary creep models agreed within their standard errors.

While the secondary creep coefficient $A$ was found to differ by a factor of 2.6 for the two geologic levels, the stress exponent $n$ and activation energy $Q$ were unaffected. No statistically significant dependence of secondary creep on drill hole, specimen size or laboratory was found. 
A very slight tendency was observed for the secondary creep rate to decrease with pressure; however, the multiple regression analysis indicated that this tendency was not statistically significant, and in excess of $93 \%$ of the behavior was captured without a confining stress dependence. A related analysis of dilatancy of secondary creep showed a slight tendency for specimens to expand at low confining stress and to compact at high confining stress under conditions of low temperature and shear stress: This tendency disappeared as the shear stress and temperature increased.

Results of secondary creep rates obtained in this study agreed well with the results of creep measurements on salt from a variety of other sources. Within the range of shear stress and temperature covered by the present data, the stress exponent was found to be 4.9 and the activation energy was found to be $12 \mathrm{kcal} / \mathrm{mole}(50 \mathrm{~kJ} / \mathrm{mole})$. There was no indication of a change to another mechanism at the highest temperature $\left(200^{\circ} \mathrm{C}\right)$ and shear stress (6000 psi or $31 \mathrm{MPa}$ ) covered in this study. Consequently, a single mechanism for the stress and temperature dependence of secondary creep is considered sufficient within this range.

Steady-state creep rates were found to be unaffected by prior stress or temperature historịes, provided that the'stress and temperature increased monotonically. The fact that reported triaxial compression and extension tests gave the same results within the scatter of the data suggests that the present results are applicable to both compressive and extensive loading. Load drop tests suggest that the present results are 
not applicable when the stress history includes stress reversals. No information is available pertaining to decreasing temperature histories.

It should be emphasized that the present results are valid in a limited stress and temperature range. It is clear from data in polycrystaline halite ${ }^{19}$ that the steady-state creep mechanism changes to one with a higher activation energy at temperatures much above $200^{\circ} \mathrm{C}$. The agreement of those data with the present data suggests that this . is likely true also for the Southeast New Mexico rock salt, and that the present results cannot be extrapolated to higher temperatures without modification.

Existing data on pure single crystal sodium chloride suggest that different steady-state creep mechanisms are operative at higher stresses. ${ }^{13}$ While the data for a number of naturally occurring rock salts are remarkably similar, it is unclear whether they are directly comparable to those for pure $\mathrm{NaCl}$. Iittle can therefore be said on the basis of the data quoted here regarding the range of validity of extrapolation of the present results to higher stresses.

Extrapolation to lower stresses is likewise uncertain. It has been suggested that creep may be absent below some (non negligible) threshold stress. The present data show significant creep rates at the lowest stresses tested. Much lower stresses result in creep rates which may be at the limit of resolution of present instrumentation, so that direct experimenlal assessment of this suggestion is likely to be difficult. Finally, a comment with regard to the uncertainty in the fit to (3) is in order. While the data for most individual creep experiments are internally consiotent, steady-state creep rates obtained from different specimens tested under nominally the same conditions may scatter by an 
order of magnitude. The experimental technique and instrumentation have been carefully checked and calibrated to eliminate experimental errors. 8,9 The scatter is attributed to variations in the material. Indeed, factors such as grain size, impurity distribution and content of accessory minerals vary from specimen to specimen.

While the individual data points may scatter by an order of magnitude, statistical analysis has resulted in a best fit to the data with a logarithmic standard deviation of 0.0887 (using results of the exponential transient creep law, Table 3). This implies that the steady-state creep rate is likely (with $95 \%$ confidence) to lie within a factor of exp ( \pm .887 ) or a factor of 2.4 of the mean value predicted by (3) with coefficients from Table 3. Since the scatter is attributed to material variations, the uncertainty of a factor of 2.4 greater or less than the mean value applies to the analysis of phenomena on a sufficiently large scale so that material variations average out. Local properties may vary from the mearl by a considerably larger factor.

The design process, when such large uncertainty intervals exist, requires care. Calculations using mean values are apt to be meaningless. Careful statistical analysis with attention to error propagation is necessary to achieve conservative predictions. 


\section{REFERENCES}

1. W. Herrmann, W. Wawersik and H. S. Lauson

Creep Curves and Fitting Parameters for Southeastern New Mexico Bedded Salt.

Sandia National Laboratories SAND-80-0087, March (1980).

2. W. R. Wawersik and D. W. Hannum

Interim Summary of Sandia Creep Experiments on Rock Salt from the WIPP Study Area, Southeastern New Mexico.

Sandia Laboratories SAND-79-0115, February (1979)

3. F. D. Hansen

Triaxial Quasi-Static Compression and Creep Behavior of Bedded

Salt from Southeastern New Mexico.

Re/Spec Inc. RSI-0055, June (1977).

Sandia Laboratories SAND-79-7045, (1979):

4. F. D. Hansen and K. D. Mellegard

Creep Behavior of Bedded Salt from Southeastern New Mexico at Elevated Temperatures.

Re/Spec Inc. RSI-0062, November (1977).

Sandia Laboratories SAND-79-7030 (1979).

5. F. D. Hansen and K. D. Mellegard

Further Creep Behavior of Bedded Salt from Southeastern New

Mexico at Elevated Temperatures.

Re/Spec Inc. - RSI-0104, December (1979).

6. D. W. Powers, et al.

Geological Characterization Report, Waste Isolation Pilot Plant

(WIPP) Site, Southeastern New Mexico Vol. II.

Sandia Laboratories SAND-78-1596, December (1978).

7. J. F. Callender and T. Ingwell

Structural Petrology of Undeformed and Experimentally Deformed

Halite samples f'rom USEKDA Site \#7 and \#9.

Sandia Laboratories SAIND-78-7076, February (1978).

8. W. R. Wawersik

Technique and Apparatus for Strain Measurements on Rock at

Constant Confining Pressure.

Rock Mech. 7; 231 (1975).

9. W. R. Wawersik

Indirect Deformation (Strain) Measurements and Calibrations ith Sandia Triaxial Apparatus for Rock Testing to $250^{\circ} \mathrm{C}$.

Sandia Laboratories SAND-79-011.4, september (1979).

10. J. Weertman

Dislocation Climb Theory of Steady state Creep.

ASIv Trans. Quart. 6́1; 681 (1yó8). 
11. The analyses were kindly performed by H. A. Davis and D. D. Sheldon of Sandia Laboratories. Advice on interpretation of statistical data was also received from $G$. P. Steck and $R$. R. Praire, also of Sandia. Laboratories.

12. W. J. Dixon

BMDP Biomedical Computer Programs (P Series), P2R Stepwise Regression.

University of California Press (1977).

13. D. E. Munson

Preliminary Deformation-Mechanism Map for Salt (With Application to WIPP). Sandia Laboratories SAND-79-0ก76, Tanuary (1979).

14. D. E. Munson and P. K. Dawson

Update of Salt Creep Model for WIPP.

Private Mcmo, Apiil (1979).

I5. K. Nair

Project Payette Phase II, Creep and Creep Rupture Criteria for Salt.

Final Report to Fenix and Scisson, Inc. by Woodward, Clyde and Assoc. and Materials Research and Development, Inc. Subcontract FSIV-688-4, Dec. (1968).

16. Project Dribble-Petrographic Examination and Physical Test of Cores, Tatum Dome, Mississippi.

U. S. Army Eng. Waterways Experiment Station Tech. Rept. 6-614, January (1963).

17. E. Thompson and E. A. Ripperger

An Experimental Technique for the Investigation of the Flow of Halite and Sylvinite.

Proc. 6th Symposium on Rock Mechanics, Rolla, Miss. (1964).

18. W. R. Wawersik, D. W. Hannum and H. S. Lauson Indicator 'l'ests f'or Dome Salt, West Hackberry, Louisiana.

Am. Geophys. Union (Abstract), Fall Meeting (1979).

19. H. C. Heard

Steady-State Flow in Polycxystalline Halite at Pressure of $?$ Kilobars, in Flow and Fracture of Rocks, ed. H. C. Heard et al. Am. Geophys. Union (1972).

20. U. Hunsche, "Das Fliessverhalten von Steinsalz - Studie zur Extrapolation von Versuchsergebnissen auf lange Zietraeume," 2. Progress Report, Research Activity SR 138; Archive No. 82 136, Bundesanstalt fuer Geowissenschaften und Rohstoffe, Hannover, Germany, February (1979). 
Table 1

Steady State Creep Rates from Exponential Fit (Eq. 1)

\begin{tabular}{|c|c|c|c|c|c|c|c|c|c|c|c|c|c|}
\hline 10 & TEST & STAGE & HOLE & SIZE & $0 \equiv P T H$ & $T$ & $T$ & $\sigma_{3}$ & $\mathbf{P}$ & $\dot{e}_{S 1}$ & ERROR & $\dot{\mathbf{e}}_{\text {S3 }}$ & ERROR \\
\hline R:S5521A & 1 & 1 & 7 & 2 & 2729.3 & 24 & 1530 & 510 & 1320 & $8 \cdot 215 E-1)$ & $2.356 E-11$ & $1.200=-67$ & $1 \cdot .03 \equiv-11$ \\
\hline R.S55018 & 1 & 2 & 7. & 2 & 2729.0 & 24 & 3024 & 518 & 1526 & $3.283 E-38$ & $2.0 .2 .5 E-5.9$ & $1.324 E-5.8$ & $7.5005-10$ \\
\hline RS550:C & 1 & 3 & 7 & 2 & $27<9.0$ & 24 & 4325 & 519 & 1.954 & $1.394 E-37$ & $3.4 \cup J E-29$ & $5.436 E-03$ & $1.9325-j 9$ \\
\hline R.S55:2A & 2 & 1 & 7 & 2 & 2715.0 & 100 & 1497 & 587 & 1088 & $2.575 E-29$ & $1.443 \varepsilon-69$ & נ. & $\hat{u}$. \\
\hline RS5503A & 3 & 1 & 7 & 2 & 2715.0 & 24 & 1495 & 2034 & $25: 2$ & $3.5855-39$ & $1.55: \bar{E}-1\}$ & 3. & 2. \\
\hline RS55038 & 3 & 2 & 7 & 2 & 2715.0 & 24 & 2968 & 2015 & 3004 & $2.714 \sum-99$ & $5.300 E-10$ & $3.878 E-09$ & $3.973 E-10$ \\
\hline RS5503C & 3 & 3 & 7 & 2 & 2715.0 & 24 & 4244 & 2244 & 3459 & $9.419 \Xi-.38$ & $3.573 E-09$ & $4.1735-38$ & $1 \cdot 8=0 E-03$ \\
\hline RS55.34A & 4 & 1 & 7 & 2 & 2711.0 & 24 & 3037 & 2012 & 3024 & $1.755 E-.28$ & $3.6025-10$ & $7.314 E-39$ & $4 \cdot 2 \cdot 3 \equiv-1 J$ \\
\hline RS55:24B & 4 & 2 & 7 & 2 & 2711.0 & 24 & 4309 & $2 J C B$ & 3444 & $: 9.2375-0.3$ & $2.57-E-09$ & $3.354 E-08$ & $1.135=-37$ \\
\hline คร5ร?รA & 5 & 1 & 7 & 2 & 2711.0 & 100 & 1509 & 1990 & 2493 & $4 \cdot 109 E-03$ & T.10:E-10 & 1. $3 \subseteq 5 E-08$ & $3.1 .00 E-1$. \\
\hline P $55535 B$ & 5 & 2 & 7 & 2 & $27: 1.0$ & 100 & 2631 & 2010 & 2887 & $5.304 E-37$ & $2.30:[-09$ & $2.312 \bar{c}-37$ & $1.2205-39$ \\
\hline AS 5506 . & 5 & 1 & 7 & $\underline{2}$ & $27: 5.5$ & 100 & 2702 & 2003 & 2904 & $4.774 E-37$ & $3.00 J E-39$ & $2.132 E-97$ & $1.30 j E-39$ \\
\hline$F \leqq 6201$ & 1 & 1 & 9 & 2 & $2668 \cdot 5$ & 24 & 1535 & $\dot{u}$ & $5: 2$ & $3.817 \equiv-11$ & $5.8275-10$ & 3. & $?$ \\
\hline$F \subseteq 6232$ & 2 & 1 & 9 & 2 & 2668.5 & 74 & 1544 & i] & 515 & $1.5 \cap 2 E-0 B$ & $4.70 J E-10$ & $-3 \cdot$ & 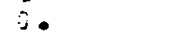 \\
\hline F: 55233 & 3 & 1 & 9 & 2 & 2622.0 & 107 & 1515 & 0 & 505 & $4.242 E-3 B$ & $5.902 E-10$ & 3. & 3 \\
\hline P. 56205 & 5 & 1 & 9 & 2 & 2674.5 & 24 & 308.8 & 2360 & 3389 & $2.711 E-0 B$ & $3.500 E-10$ & $1.161 \equiv-5.3$ & $1.73,3:-13$ \\
\hline P.562:5 & 6 & 1 & 9 & 2 & 2674.5 & 73 & 3041 & 2602 & 3515 & $4.5165-37$ & $2.600 \bar{E}-09$ & 1. $B 8 \cup=-97$ & $1 \cdot 40:=-03$ \\
\hline RS6207 & 7 & 1 & 9 & 2 & 2679.0 & 135 & $3 c 66$ & $251 \mathrm{~J}$ & 3532 & $2.553 E-36$ & $4.10: E-C B$ & $0.195 E-07$ & $2.36 J E-39$ \\
\hline$R 56298$ & 8 & 1 & $\exists$ & 2 & 2625.0 & 105 & 1559 & 2978 & 3498 & $4.595=-03$ & $3.900 E-10$ & $2.211 E-68$ & $2 \cdot 5005-1]$ \\
\hline 256239 & 7 & 1 & 9 & 2 & 2578.0 & 24 & $1 \equiv 2 j$ & 3 & $5: 7$ & $2 \cdot 152 \Xi-79$ & $4.68[[-1]$ & 2 & J. \\
\hline $356210 \mathrm{~A}$ & 10 & $!$ & 马 & 2 & 2536.0 & 24 & 1421 & 2513 & $3:: 2$ & $3.371=-39$ & $1.92 n=-10$ & $2.395 \equiv-79$ & $1.043 \equiv-10$ \\
\hline$R 562108$ & 13 & 2 & 9 & 2 & $2636 . \bar{u}$ & 24 & 3277 & 2425 & 3451 & $2.585 \equiv-33$ & $5 \cdot 32: 5-1]$. & $1.315 \Xi-18$ & $2.72] \Xi-10$ \\
\hline
\end{tabular}


Steady State Creep Rates from Exporiential Fit (Eq. 1)

\begin{tabular}{|c|c|c|c|c|c|c|c|c|c|c|c|c|c|}
\hline IO & TEST & STAGE. & TOLE & SIZE & $D \subseteq P T H$ & $T$ & $T$ & $\sigma_{3}$ & $\mathbf{p}$ & $\dot{e}_{s 1}$ & ERROR & $\dot{\mathrm{e}}_{53}$ & ERROR \\
\hline 2.56211 & 11 & 1 & 9 & 2 & 2679.0 & 103 & $1<95$ & $j$ & 498 & $1.345 E-07$ & $3.20 ? E-09$ & ). & 0. \\
\hline RS6212A & 12 & 1 & 9 & 2 & 2678.3 & 105 & 1558 & 2453 & 2769 & $a .451\ulcorner-3 d$ & $1.280 E-09$ & $3.991 \equiv-58$ & $8 \cdot 5=n=-10$ \\
\hline$R S 6212 B$ & 12 & 2 & 9 & 2 & 2678.1 & 107 & 3118 & 2570 & 3609 & $3.4895-36$ & $1.190 E-07$ & $1.631 E-36$ & $5 \cdot 5: 35-38$ \\
\hline RSó:213 & 13 & 1 & 9 & 2 & 2605.5 & 24 & 450.0 & 1971 & 3473 & $8.758 E-38$ & $1.67: E-? 9$ & $4.315 E-08$ & $7 \cdot 7: 3 \equiv-13$ \\
\hline 856214 & 14 & 2 & 9 & 2 & 2678.7 & 24 & $58 \in 4$ & 1467 & 3422 & $5.74 \exists E-07$ & $7.80 ? 5-59$ & $2.811 E-i 7$ & $3.930 E-39$ \\
\hline$C A \quad 152 A$ & 1 & 1 & 9 & 4 & 2078.0 & 22 & 1999 & 485 & 1152 & $1 .: 225-09$ & $2.50: E-11$ & 3 & נ. \\
\hline$C A 102 B$ & 1 & 2 & 9 & 4 & 2078.2 & 22 & 4493 & 530 & 2904 & $7.714 c-08$ & $3.100 E-09$ & $4.496 \bar{c}-08$ & $1.713 E-39$ \\
\hline CA $1: 9$ & 2 & 1 & 9 & 4 & 2.383 .0 & 22 & $25: 74$ & 501 & 1432 & $2.95 J E-29$ & $1.000 E-11$ & $2.641 \equiv-59$ & $4.50 J \equiv-11$ \\
\hline $\begin{array}{cc}C A & 110\end{array}$ & 2 & 2 & 9 & 4 & 2083.0 & 22 & 4436 & 528 & 2097 & $6.712 \Xi-38$ & $3.310 E-29$ & $2.521 E-08$ & $4.190 \equiv-97$ \\
\hline CA 1.:34 & 3 & 1 & $\exists$ & 4 & 2078.5 & 22 & $1 \in 92$ & 3005 & 3569 & $4.7] 7 E-10$ & $1.150 z-11$ & 0. & $2 \cdot$ \\
\hline$C A 133 B$ & 3 & 2 & 9 & 4 & 2078.5 & 22 & $4: 57$ & 3015 & $44 j 1$ & $3.342 E-39$ & $\therefore .433 E-03$ & $1.3 a ́ 6 E-J 8$ & $8.73 J \equiv-1 J$ \\
\hline CA $1: 34$ & 4 & 1 & 9 & 4 & 2083.5 & 22 & 2520 & 3214 & 3987 & $2.534 E-09$ & $5.80: E-11$ & $5.9995-10$ & $4.672 \equiv-11$ \\
\hline CA $: 135$ & 4 & 2 & 9 & 4 & 2083.5 & 22 & 4437 & 3032 & 4511 & $1.4825-138$ & $2.400 E-13$ & $7.332 \equiv-09$ & $1 \cdot 270 \equiv-13$ \\
\hline CA $1: 3$ & 5 & i & 9 & 4 & 2625.0 & 22 & 1186 & 521 & 915 & $1.376 E-10$ & $3.50 J E-12$ & 3 & 2 \\
\hline CA 111 & 5 & 2 & 9 & 4 & 2525.0 & 22 & 224.7 & 515 & 1254 & $2.374 E-99$ & $3.90: J E-11$ & $1.694[-09$ & $2.70 J E-11$ \\
\hline CA 112 & 5 & 3 & 9 & 4 & 2625.0 & 22 & 3298 & 517 & 1616 & $2.5 \geq 45-38$ & $3.20 \mathrm{JE}-1 \mathrm{3}$ & $1.395=-8.8$ & $1.100 \equiv-10$ \\
\hline CA 121 & 6 & 1 & 9 & 4 & 2677.0 & 22 & 11.27 & 3009 & 3385 & $1.555=-10$ & $9.70>E-12$ & $\therefore$ & 0 \\
\hline CA $1 \geq 2$ & 6 & 2 & 9 & 4 & 2677.0 & 22 & 3355 & 3012 & 4130 & $1.588 \equiv-33$ & $4.70 ; E-1 D$ & $9.372 E-39$ & $2.74 .5 \equiv-10$ \\
\hline CA 118 & 7 & 1 & 9 & 4 & 2672.5 & 200 & 994 & 33 & 364 & $1.153 E-j 8$ & $=10 . E-1 ?$ & נ. & $\therefore$ \\
\hline CA $1: 97$ & 8 & 1 & 9 & 4 & 2524.0 & 103 & 2675 & 513 & 811 & $9.325 E-07$ & $1.30 \leqslant 5-11$ & $4.575 \equiv-39$ & $2.050=-10$ \\
\hline CA 114 & 9 & 1 & 9 & 4 & 2686.5 & 100 & 388 & 514 & 843 & $2.730 \subseteq-07$ & $\dot{2} .70 n=-11$ & $1.165=-? 9$ & $2.413 \equiv-10$ \\
\hline
\end{tabular}


Table 1 (continued)

Steady State Creep Rates from Exponential Fit (Eq. 1)

\begin{tabular}{|c|c|c|c|c|c|c|c|c|c|c|c|c|c|}
\hline ID & TEST & STAG: & $+O L E$ & SIZE & DEPTH & $T$ & $T$ & $\sigma_{3}$ & $\mathbf{p}$ & $\dot{\mathrm{e}}_{\mathrm{s}_{1}}$ & ERROR & $\dot{\mathbf{e}}_{53}$ & ERROR \\
\hline CA 115 & 9 & 2 & 9 & 4 & $268 E .0$ & 100 & 2356 & 517 & $13: 2$ & $4.951 \equiv-38$ & $4.361 E-08$ & $6 \cdot \dot{U} 22 E-6 \theta$ & $7.6535-19$ \\
\hline CA 117 & 10 & 1 & 9. & 4 & 2671.0 & 200 & 914 & 3027 & 3332 & $2.091 E-39$ & $1.60 j 5-11$ & 3. & 3. \\
\hline CA 119 & 10 & $=$ & $\exists$ & 4 & 2671.0 & $10:$ & 2269 & 3019 & 3755 & $3.217 E-98$ & $2.34 n E-39$ & $1.399 \varepsilon-08$ & $2.30 ! E-37$ \\
\hline CA 115 & 11 & $!$ & 9 & 4 & 2638.0 & 200 & 994 & 525 & 857 & $1.7925-37$ & $4.402 \bar{c}-09$ & $9.6 \div 2 \equiv-08$ & 3.נ. \\
\hline CA 120 & 12 & 1 & 9 & 9 & 2658.9 & 232 & 997 & 2751 & 3293 & $2.415 \equiv-07$ & $3.300 \bar{E}-5.9$ & $1.086 E-07$ & $9.430 \leq-09$ \\
\hline CA 100 & 13 & $:$ & 7 & 4 & 2777.0 & 22 & 4714 & 521 & 2392 & $4.168=-27$ & $5.70=E-09$ & $2.765 E-.77$ & $3.730 E-09$ \\
\hline CA 101 & 14 & 2 & 7 & 4 & 2741.5 & 22 & 2106 & 11 & 713 & 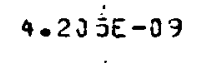 & $4.410 \bar{c}-10$ & $5.162 E-10$ & 2. \\
\hline RSTA:1 & 1 & 1 & 9 & 2 & 2501.2 & 24 & 1510 & 0 & 5.33 & $3.344 E-09$ & $7.80=E-11$ & $\therefore$ & 3. \\
\hline RST901A & 1 & 1 & 9 & 2 & 2553.7 & 24 & 1502 & c & 501 & $4 \cdot 242 z-11$ & $6.855 E-11$ & $\therefore$ & 3. \\
\hline RST901B & 1 & 2 & 9 & 2 & $25[3.7$ & 75 & 1477 & 0 & 492 & $4 \cdot 0: 3 E-39$ & $1.03 \cap E-10$ & 3 & ù. \\
\hline RST9D2 & 2 & 1 & 9 & 2 & 2442.2 & 24 & 2984 & 2509 & 35.24 & $4.534 E-09$ & $9.60 n E-11$ & $2.208 \equiv-67$ & $4 \cdot 7 \cdot 00 \Sigma-11$ \\
\hline RSI9:3 & 3 & 1 & 9 & 2 & 2442.8 & 24 & 2983 & 538 & $15 j 2$ & 3.35TtE-09 & $1 . T 1 D E-13$ & $4.231 \hat{c}-09$ & $1.2505-10$ \\
\hline$R 57904$ & 4 & 1 & $\exists$ & 2 & 2509.1 & 24 & 1536 & $30: 6$ & 3518 & $1.578 E-09$ & $3.600 E-11$ & je & $j$ \\
\hline RS.7904A & 4 & 1 & 9 & 2 & 2501.2 & 24 & 1532 & 3005 & 3516 & $3.103 E-10$ & $8.002 E-12$ & $4.770 \equiv-11$ & $1.701 E-11$ \\
\hline 2579048 & 4 & 2 & 9 & 2 & $250: 1.2$ & 105 & $15 \varepsilon_{8}$ & 3008 & 3511 & $1.756 \bar{E}-383$ & $4.203 E-10$ & $7.531 \varepsilon-09$ & $3.250=-10$ \\
\hline RST9:5 & 5 & 1 & 9 & 2 & 2439.2 & 75 & 1506 & 3001 & 3503 & $2.4165-37$ & $2.100 E-11$ & $1.08 D E-09$ & $2.300 E-12$ \\
\hline RS7905 & 6 & 2 & 9 & 2 & 2442.8 & 105 & 1483 & 3003 & 3497 & $7.685 \Xi-09$ & $4.46: ?=-1 ?$ & $4.732 \equiv-09$ & 3. $58 J \equiv-10$ \\
\hline$R \leqslant 79 J 7$ & 7 & 1 & 9 & 2 & 2439.2 & 210 & 1471 & 3003 & 3493 & $2.575 \equiv-06$ & $1.7 C .2 E-C B$ & $1.3365-06$ & $1.10 J E-D B$ \\
\hline$R S 79: 58$ & 8 & 1 & 9 & 2 & $24<1.9$ & $21 ;$ & 789 & 2 & 263 & $5.731=-.98$ & T.coge-1. & 3. & 1. \\
\hline RSTOPO & $\exists$ & 2 & 9 & 2 & 2442.2 & 210 & 791 & 537 & 171 & $\because 215 \pm-58$ & $3.200 E-10$ & $4.5795-\overline{1} 8$ & $2 \cdot 200 \leq-10$ \\
\hline$R \cong 7913$ & 10 & 1 & 9 & 2 & 2493.8 & $21:$ & 797 & 2992 & 3258 & $5.1125-78$ & $5.75: E-1]$ & $3.634 \equiv-\cap 8$ & $2.403 E-1]$ \\
\hline
\end{tabular}


Steady State Creep Rates from Logarithmic Fit (EC. 2)

\begin{tabular}{|c|c|c|c|c|c|c|c|c|c|c|c|c|c|}
\hline Io & TEST & STAGE & HOLE & SIZE & $O \equiv P T H$ & $\mathbf{T}$ & $T$ & $\sigma_{3}$ & $\mathbf{P}$ & $\dot{e}_{s 1}$ & ERRCP. & $\dot{\mathrm{e}}_{53}$ & ERROR \\
\hline ZS55013 & 1 & 2 & 7 & 2 & $27 \geq 9.0$ & 24 & 3524 & 518 & 1526 & $1.294 E-03$ & $2.990 E-09$ & $7.083 E-69$ & $1.318 E-09$ \\
\hline RS55:1C & 1 & 3 & .7 & 2 & $27 \geq 9.0$ & 24 & $43: 5$ & 519 & 1954 & $5.891 E-08$ & $2.670 E-09$ & $3.4965-08$ & $1.370 E-.39$ \\
\hline RS53.2A & 2 & 1 & 7 & 2 & 2715.0 & 100 & 1497 & 589 & 1088 & $1.361 E-09$ & $1 . B 3 C E-C 9$ & 3 & 0. \\
\hline AS5503A & 3 & 1 & 7 & 2 & 2715.0 & 24 & 1495 & 2034 & 2532 & $2.012 E-09$ & $2.560 \equiv-10$ & נ. & נ. \\
\hline RS55J38 & 3 & $\geq$ & 7 & 2 & 2715.0 & 24 & 2758 & 2015 & 3004 & $\therefore .481 E-J 8$ & $1.052 E-69$ & $5 . ن 45 E-i 9$ & $3.850 \equiv-10$ \\
\hline RS5503C & 3 & 3 & 7 & 2 & 2715.0 & 24 & 4244 & 204.4 & 3459 & $4.9 J 1 E-08$ & $2.900 E-09$ & $1.340 E-c 8$ & $1.510 E-89$ \\
\hline RS5504A & 4 & 1 & 7 & 2 & 2711.0 & 24 & 3337 & 2012 & 3924 & $3.153 E-39$ & $5.0605-10$ & $3 \cdot$ & $3 \cdot$ \\
\hline 2555048 & 4 & 2 & 7 & 2 & 2711.0 & 24 & 43.9 & 200.8 & 3444 & $4.977 E-133$ & $2.200 \equiv-0.9$ & $2.187 E-08$ & $1.273 E-59$ \\
\hline RS5505A & 5 & 1 & 7 & 2 & 27.11 .0 & 100 & 1539 & 1990 & 249.3 & $2.837 E-08$ & $6.10 n \Xi-1 ?$ & $1.361 E-38$ & $3.800 E-1 \mathrm{~J}$ \\
\hline RS55059 & 5 & 2 & 7 & 2 & 2711.0 & 100. & 2531 & 2010 & 2887 & $4.244 E-07$ & $3.600 \bar{E}-09$ & $1.962 E-37$ & $2.100 E-29$ \\
\hline 2555005 & 5 & 1 & 7 & 2 & 2715.5 & 100 & 2302 & $2 \mathrm{cos}$ & 2934 & $4.153 E-07$ & $6.100 \equiv-09$ & $1.852 E-37$ & $2.732 \equiv-29$ \\
\hline 255202 & 2 & 1 & 5 & 2 & 2658.5 & 74 & 1544 & 9 & 515 & $1.215 \bar{E}-98$ & $5.600 \equiv-10$ & 3. & $\therefore$ \\
\hline RS6203 & 3 & 1 & 9 & 2 & 2622.0 & 107 & 1515 & o & 535 & $2.8575-08$ & $8 \cdot 40: \equiv-10$ & נe & $3 \cdot$ \\
\hline 296235 & 5 & 1 & 3 & 2 & 2674.5 & 24 & 3388 & 2360 & 3389 & $1.839 \bar{E}-38$ & $6.700 \equiv-10$ & $3.2 C 8 E-09$ & $2.7405-10$ \\
\hline RSS20S & 6 & 1 & 9 & 2 & 2574.5 & 73 & $3=41$ & 2602 & 3615 & $4.095 E-07$ & $5.600=-0.7$ & $1 \cdot 588=-37$ & $2.7 \div 9=-37$ \\
\hline $9562: 7$ & 7 & 1 & 9 & 2 & 2679.0 & 105 & $3: 266$ & $251 ?$ & 3532 & $1.434 E-36$ & $4.30 .2=-0.8$ & $7.093 E-57$ & $2.3335-18$ \\
\hline RS6258 & 8 & 1 & 3 & 2 & $26 \pm 5.0$ & 105 & $15 \equiv 9$ & 2978 & 3473 & $4.153 \bar{\varepsilon}-38$ & $6 \cdot 23 i 5=-1 \cdot 3$ & $2.026 E-03$ & $4 \cdot 3 i] \bar{L}-10$ \\
\hline$R S 6209$ & 9 & 1 & 9 & 2 & 2678.0 & 24 & $1 \overline{20}$ & 3 & 5137 & $4.7 .35 \equiv-1 j$ & $8.798=-10$ & 3. & $\therefore$ \\
\hline RS $6212 \mathrm{~A}$ & 10 & $=$ & $\exists$ & 2 & 2646.0 & 24 & 1481 & 2519 & 3012 & $2.493 E-39$ & $2.0400-13$ & $1.437=-09$ & $2.123 \equiv-10$ \\
\hline 2562128 & $: 3$ & 2 & 7 & 2 & $26: 5.0$ & 24 & $3: 77$ & 2425 & 3451 & $1.523 \equiv-69$ & $8.250=-1 ;$ & $3.217=-39$ & $4.74 J E-20$ \\
\hline RSS211 & 11 & 1 & 9 & 2 & $2579 . \bar{E}$ & 103 & 1495 & 3 & 478 & i.10J $\equiv-97$ & $3.10=E-6.9$ & $3 \cdot$ & $\therefore$ \\
\hline
\end{tabular}


Table 2 (continued)

Steady State Creep Rates from Logarithmic Fit (Eq. 2)

\begin{tabular}{|c|c|c|c|c|c|c|c|c|c|c|c|c|c|}
\hline ID & TEST & STAGE & TOL & SIZE & DEPTH & $T$ & $T$ & $\sigma_{3}$ & $\mathbf{P}$ & $\dot{\mathrm{e}}_{\mathrm{S} 1}$ & ERROR & $e_{53}$ & ERROR \\
\hline RS6212A & 12 & 1 & 9 & 2 & 2678.3 & 106 & 1558 & 2453 & 2969 & $6.50 \mathrm{~B} \vec{E}-08$ & $2.310 E-09$ & $2.969 E-38$ & $1.720 E-09$ \\
\hline PS6212B & 12 & 2 & 9 & 2 & 2678.3 & 107 & 3118 & 2570 & 3609 & $1.554 E-06$ & $2.58 c \tilde{c}-07$ & $7.247 E-06$ & $1.210 E-06$ \\
\hline RS6213 & 13 & 1 & 3 & 2 & 2505.5 & 24 & 4535 & 1971 & 3473 & $5.380 E-08$ & $1.80 C E-09$ & $2.551 E-08$ & $8.6005-10$ \\
\hline RS6214 & 24 & 1 & 9 & 2 & 2678.7 & 24 & $.5854^{\circ}$ & 1467 & 3422 & $4.397 E-37$ & $7.90 .5 E-09$ & $2.158 \varepsilon-67$ & $4 \cdot \cos 0=-29$ \\
\hline CA $132 A$ & 1 & 1 & 3 & 4 & $2: 78.8$ & 22 & 1999 & 486 & 1152 & $5.1235-13$ & $1.64 n E-11$ & נ. & נ. \\
\hline$C A \quad 122 B$ & 1 & 2 & 9 & 4 & 2678.0 & 22 & 4493 & 506 & 2004 & $4.827 \leq-08$ & $4 \cdot 880 E-09$ & $2.780 E-08$ & $2.750 E-? 9$ \\
\hline CA 109 & 2 & 1 & 9 & 4 & 2083.0 & 22 & 2974 & 501 & 1492 & $2.062 E-109$ & $9.105 E-11$ & $2.099[-i \pi 9$ & $5.723 E-11$ \\
\hline CA 110 & 2 & $\underline{2}$ & 9 & 4 & 2583.0 & .22 & 4436 & 528 & 2307 & $3.376 E-03$ & $7.52: 5-09$ & $-4.0995-29$ & $8.728 E-09$ \\
\hline CA $103 A$ & 3 & 1 & 9 & 4 & 2078.5 & 22 & 1692 & 3905 & 3569 & $1.913 E-13$ & $1.065 E-11$ & 3 & 3. \\
\hline CA 1933 & 3 & 2 & 9 & 4 & $2378 \cdot 5$ & 22 & 4157 & 3013 & 4401 & $\Xi 291 E-08$ & $1.87 C E-09$ & $1 \cdot 15 \overline{5} \Xi-08$ & $1 \cdot 38 ? E-39$ \\
\hline C4 104 & 4 & 1 & 9 & 4 & 2083.5 & 22 & 2920 & 3014 & 3987 & $2.327 \equiv-09$ & $5.400 E-11$ & $4.529 E-10$ & $2.2335-11$ \\
\hline CA 165 & 4 & 2 & 9 & 4 & 2083.5 & 22 & 4437 & 3032 & 4511 & $8.435 E-09$ & $1.90 \mathrm{DE}-10$ & $4 \cdot .717 E-09$ & $1.30 ? 5-13$ \\
\hline$=4138$ & 5 & 1 & 9 & 4 & 26.25 .0 & 22 & 1186 & 520 & 915 & $4 \cdot 55.] E-11$ & $5.17 \mathrm{CE}-12$ & $\dot{s} \bullet$ & $\hat{i} \cdot$ \\
\hline$=1112$ & 5 & 2 & 9 & 4 & $26.25 \cdot 0$ & 22 & 2247 & 515 & 1264 & $1.431 \Xi-.37$ & $3.600 E-11$ & $1.416=-09$ & $4 \cdot 5 ? 0 E-11$ \\
\hline$=1112$ & 5 & 3 & 9 & 4 & 2525.0 & 22 & 3298 & 517 & 1616 & $1.745 E-38$ & $3 \cdot 5 U ? E-10$ & $1 \cdot 210 \equiv-38$ & $1.630 \equiv-13$ \\
\hline$=1121$ & 5 & 1 & 9 & 4 & 2577.0 & 22 & 1127 & 3039 & 3385 & $2 \cdot 841 \equiv-11$ & $7.570 \bar{c}-12$ & 2. & je \\
\hline$=1122$ & 6 & 2 & 9 & 4 & 2677.0 & 22 & 3355 & 3012 & 4131 & $1.262 E-.99$ & $4.200 E-12$ & $7.579 E-39$ & $2.413 \mathrm{E}-20$ \\
\hline CA 118 & 7 & 1 & 9 & 4 & $2572 \cdot 5$ & $10 C$ & 994 & 33 & 364 & $8.547 \Xi-07$ & $7.5275-1]$ & $\therefore$ & 3 \\
\hline$=2 \quad 137$ & 8 & 1 & 9 & 4 & 2524.0 & $10:$ & 1675 & 513 & 971 & $6.764 \equiv-97$ & $1.60: 5-19$ & $3.7590-07$ & $4 \cdot 240 \equiv-10$ \\
\hline C4, 114 & 9 & 1 & 7 & 4 & 2036.0 & $10:$ & 988 & 514 & 343 & $2.5135-27$ & $3.7005-11$ & $5.931[-13$ & $6.4725-1)$ \\
\hline
\end{tabular}


Steady' State Creep Rates from Logarithmic Fit (Eq. 2)

\begin{tabular}{|c|c|c|c|c|c|c|c|c|c|c|c|c|c|}
\hline 10 & TEST & STAGE & TOLE & SIZE & DEगTH & $T$ & $T$ & $c_{3}$ & $\mathbf{P}$ & $\dot{\mathbf{e}}_{\text {s1 }}$ & ERRCR & $\dot{\mathrm{e}}_{\mathrm{S3}}$ & ERROR \\
\hline CA 116 & 9 & 2 & 9 & 4 & $2636 . J$ & 100 & 2.356 & 517 & 1302 & $9.653 E-) 8$. & $4.360 \mathrm{E}-08$ & $4.110 E-0 B$ & $1.735 E-J 8$ \\
\hline CA 117 & 10 & 1 & 9 & 4 & 2671.0 & $10:$ & 914 & $30=7$ & 3332 & $1.9805-07$ & $3.200 E-11$ & o. & 0. \\
\hline CA 117 & 10 & 2 & 9 & 4 & 26.71 .0 & 100 & $22: 9$ & 3019 & 3755 & $4.476 E-08$ & $2.39 c[-09$ & $3.687 \equiv-09$ & $3.368 E-n 9$ \\
\hline CA 115 & 11 & 1 & $\boldsymbol{3}$ & 4 & 2588.0 & $20 \bar{u}$ & 994 & 525 & 357 & $1.353 E-07$ & $6.90 a[-09$ & $T .518 E-38$ & $5.430 \equiv-j 9$ \\
\hline CA $: 2:$ & 12 & 1 & 3 & 4 & $2568.0 ?$ & 200 & 997 & 2951 & 3283 & $2.361 E-37$ & $3.12: E-69$ & $1.331 \equiv-07$ & 7.02JE-29 \\
\hline$C A 132$ & 13 & 1 & ग & 4 & 2777.0 & 22 & 4714 & $5 \geq 1$ & 2032 & $3 . \exists 1 \exists[-37$ & $1.14: \vdots-\dot{0} \theta$ & $2.612 E-07$ & $8.32 J E-39$ \\
\hline$C A 131$ & 14 & 2 & $\pi$ & 4 & 2741.0 & $2=$ & 2106 & 11 & 713 & $3.455 E-07$ & $7.175 \equiv-12$ & $3.841=-10$ & $5.424 E-10$ \\
\hline RST701 & 1 & 1 & 9 & 2 & 2531.2 & 24 & 2510 & $\hat{0}$ & 503 & $1.467 E-J 9$ & $7.200 \equiv-11$ & 0. & $\therefore$ \\
\hline RS 79013 & 1 & 2 & 9 & 2 & 2503.7 & 75 & 1477 & J & 492 & $3.564 E-03$ & $2.23 J E-16$ & נ. & : \\
\hline RST9:2 & 2 & 1 & 9 & 2 & 2442.2 & 24 & 2984 & 2509 & 3504 & $3.344 \tau-07$ & $6.09 x-11$ & $1.739=-i 9$ & $4.100 E-11$ \\
\hline RS7903 & 3 & 1 & 9 & 2 & 2442.8 & 24 & 2983 & 508 & 1532 & $5.292 E-39$ & $1.47 ., E-1]$ & $2.771 E-27$ & $1.190 E-10$ \\
\hline RST9C4 & 4 & 1 & 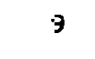 & 2 & 2509.1 & 24 & 1536 & $30: 96$ & 3518 & $4.435 E-10$ & $3.24 C E-11$ & 3. & $\therefore$ \\
\hline RST904A & 4 & 1 & $\exists$ & 2 & {$[531.2$} & 24 & 1532 & 3005 & 3516 & $1.751 E-10$ & $1.65[E-11$ & $-4.379 \equiv-11$ & $3.230 E-11$ \\
\hline RS7904B & 4 & 2 & 3 & 2 & $=501.2$ & 105 & 1508 & 3608 & 3511 & $1.190 E-98$ & $4.90[E-1]$ & $4.335 E-07$ & $4.27 J E-10$ \\
\hline RST9?5 & 5 & 1 & 9 & 2 & 2439.2 & 75 & 1536 & 3601 & $35: 3$ & $2.0355-.07$ & $2.70:[-11$ & $9.192 E-10$ & $3.410 E-11$ \\
\hline RST925 & 6 & $\vdots$ & 9 & 2 & 2.442 .8 & 165 & 1488 & 3603 & 3497 & $8.644[-69$ & $4.96 \theta[-1]$ & $4.291 \equiv-69$ & $5.530=-10$ \\
\hline RS7907 & 7 & 1 & 9 & 2 & 2439.2 & 210 & 1471 & 3003 & 3493 & $2.3805-35$ & $4.20: 2 \bar{c}-0 B$ & $1.075 \Xi-26$ & $2.33 J E-108$ \\
\hline RS 7908 & 8 & 1 & 9 & 2 & 20441.9 & 210 & 789 & u & 263 & $2.479 E-38$ & $5.55^{\prime} \equiv-1.3$ & 3. & 3. \\
\hline RS3909 & 9 & 1 & 9 & 2 & $\equiv 442.2$ & 210 & 791 & 5.7 & 771 & $6.855 E-28$ & $7 \cdot 2: \vdots \equiv-1]$ & $3.353 E-28$ & $5.2\}] E-1]$. \\
\hline$R 5791 \mathrm{C}$ & 10 & 1 & 9 & 2 & $\geqq 443.8$ & 210 & 197 & 2992 & 3258 & $5.3: 45-38$ & $8.5: \sum \equiv-1 ?$ & $2.774 E-58$ & $5.5 E J E-10$ \\
\hline
\end{tabular}


Table 3

Secondary Creep Constants

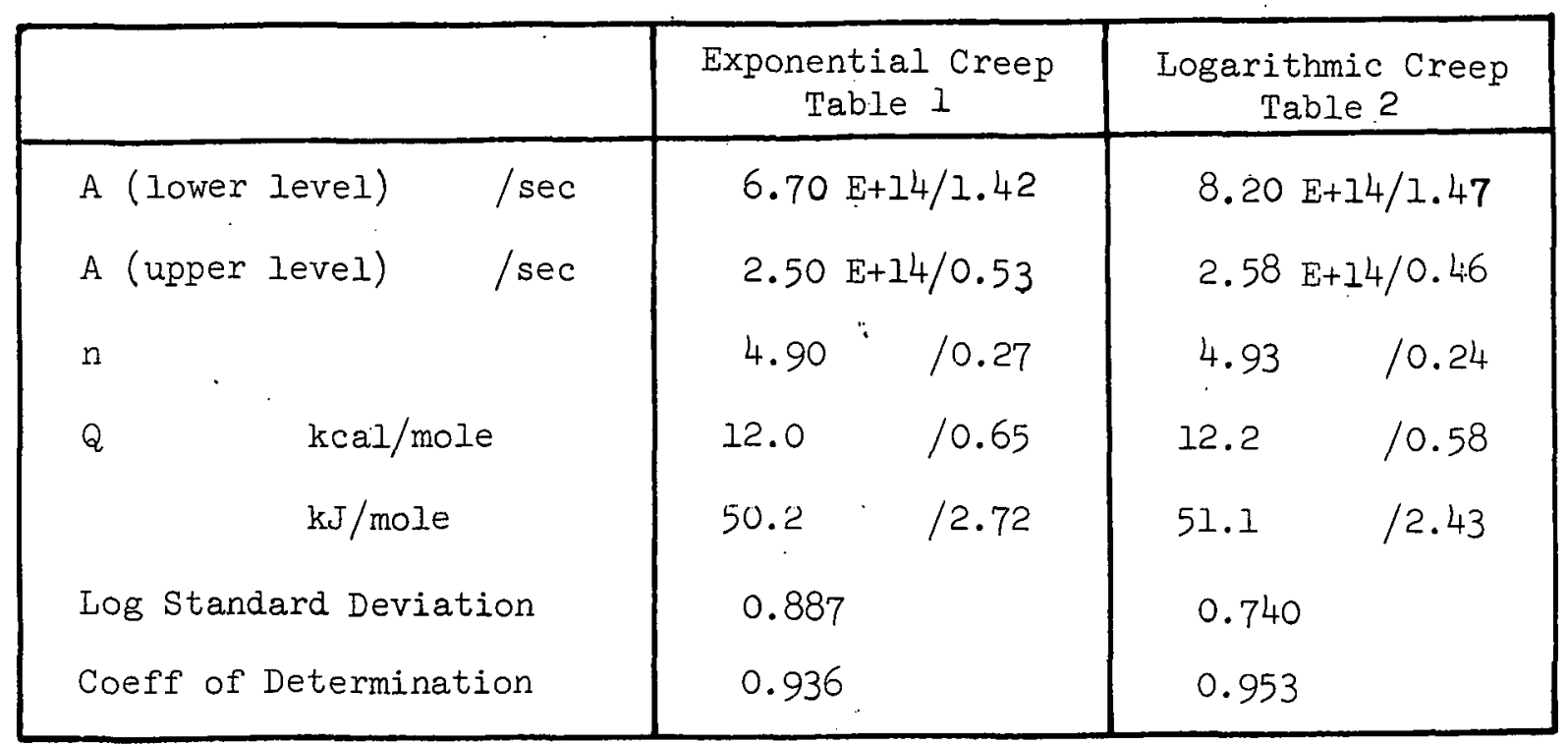

Values are followed by a slash and their standard errors, the exponent of the error being understood to be the same as that of the value. 
-able 4

Results for Laad Drop Tests, Exponential Fit (Eq. 1)

\begin{tabular}{|c|c|c|c|c|c|c|c|c|c|c|c|c|c|c|}
\hline & IO & TEST & STAG: & HOLE & SIZE & DEPTH & $\mathbf{T}$ & 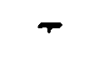 & $a_{3}$ & $\mathbf{P}$ & $\dot{\mathrm{e}}_{\text {S1 }}$ & ERROR & $\dot{\mathbf{e}}_{53}$ & ERROR \\
\hline CA & 105 & 4 & 3 & 9 & 4 & 2083.5 & 22 & 2948 & 3953 & 4016 & $1.891 E-10$ & 6. & 5. & -0 \\
\hline$C A$ & 113 & 5 & 4 & 9 & 4 & 2625.0 & 22 & 2265 & 514 & 1269 & $3.021 E-10$ & $1: 40 \mathrm{CE}-11$ & $5.319 E-10$ & $4.230 E-11$ \\
\hline
\end{tabular}




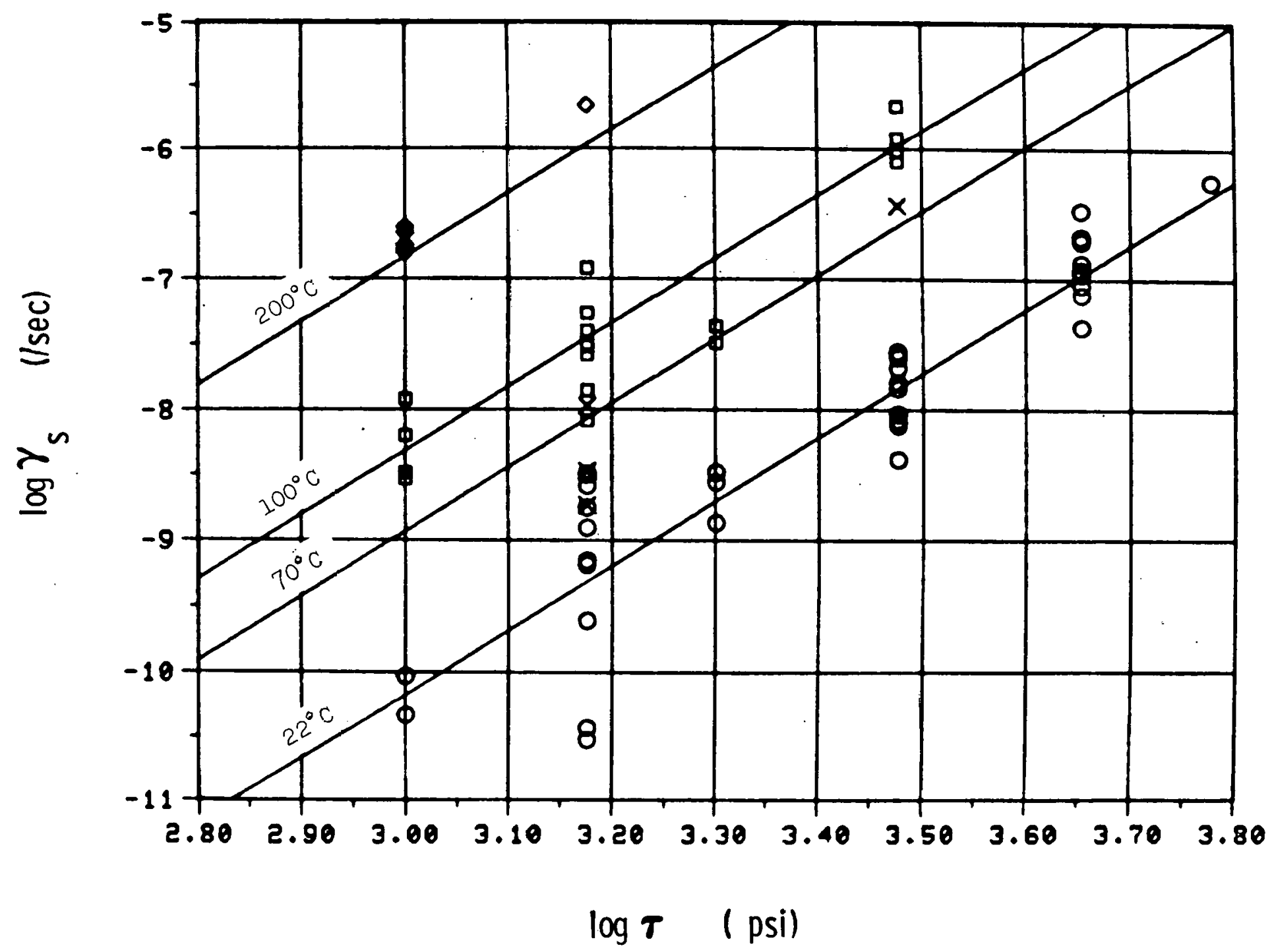

Fig. 1. Scaled Exponential Secondary Creep Rate vs. Shear Stress ( T: $022^{\circ} \mathrm{C}, \times 70^{\circ} \mathrm{C}, \quad \square 100^{\circ} \mathrm{C}, \diamond 200^{\circ} \mathrm{C}$ ) 


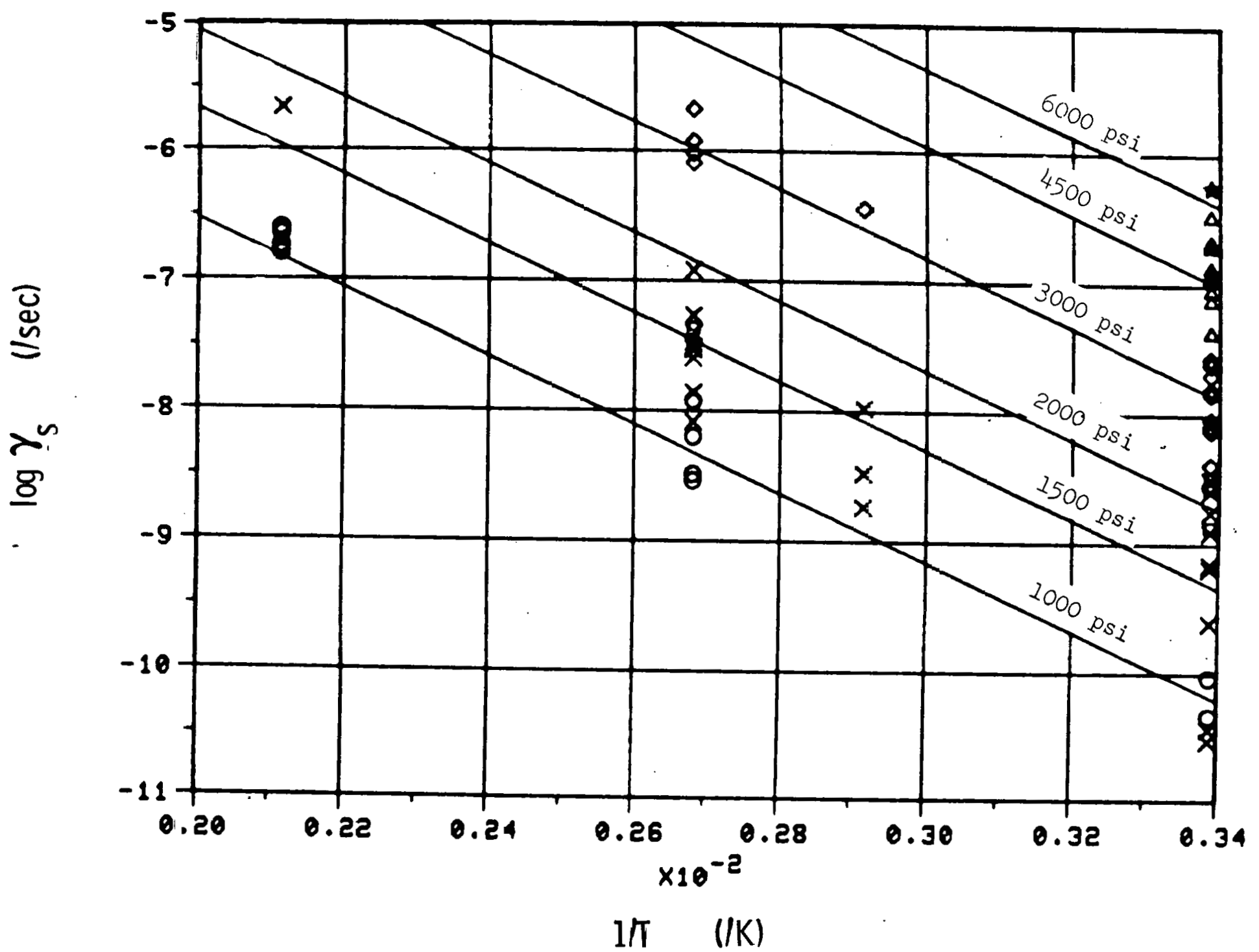

Fig. 2. Scaled Exponæntial Secondary Creep Eate rs. Temperature ( $T: 01000 \mathrm{psi}, \times 1500 \mathrm{psi}, \boldsymbol{\nabla} 2000 \mathrm{psi}, \diamond 3000 \mathrm{psi}$, 


\section{PAGES 35 to 36 WERE INTENTIONALLY LEFT BLANK}




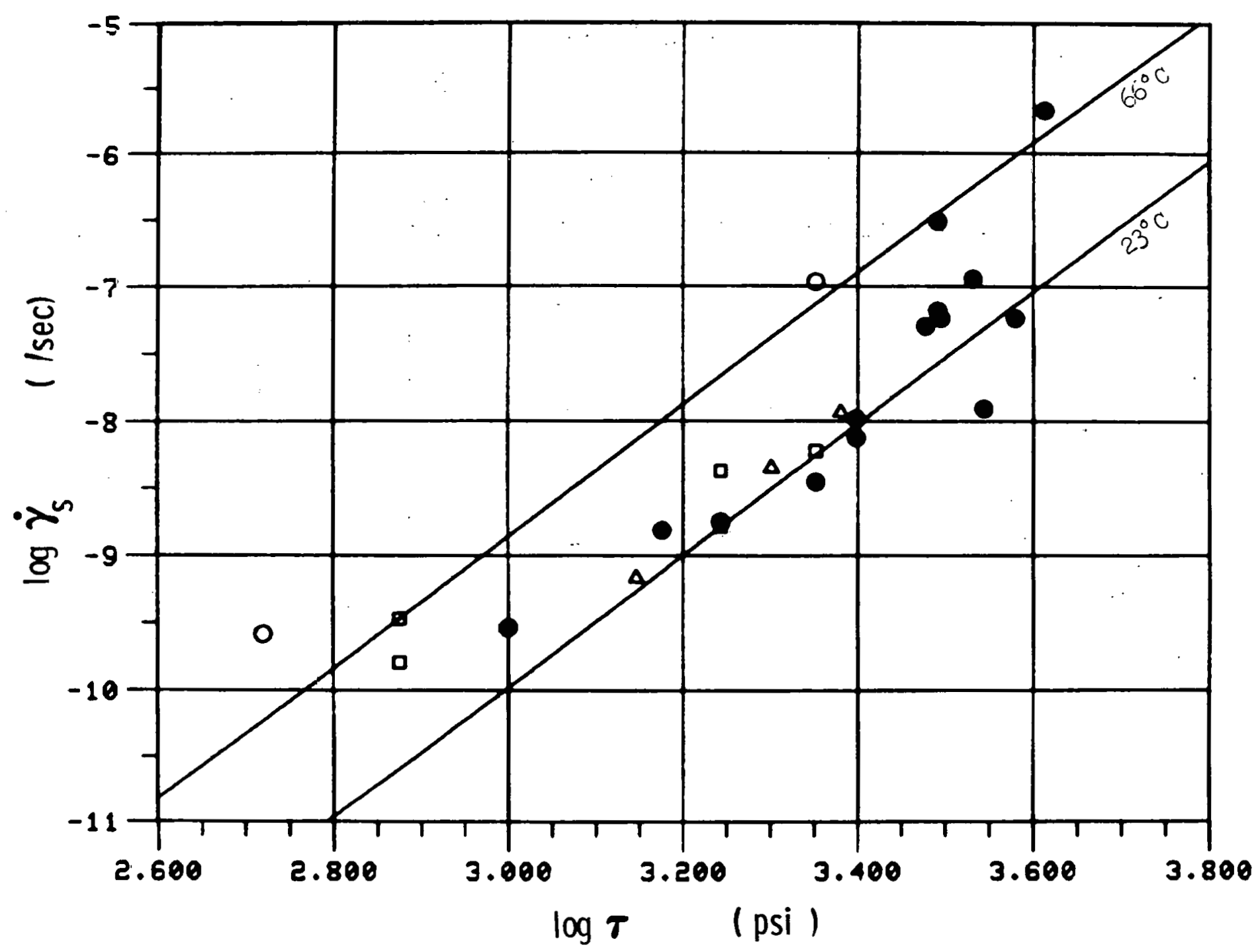

Iig. 5. Sealed Secondary Creep Rates vs Shear Stress for Tatum Dome Salt 15,16 (T: $023^{\circ} \approx, \square 66^{\circ} \mathrm{C}$ ) and Grand Saline and Hockley Mine Salt 17

(T: $\Delta 23^{\circ} \mathrm{z}$ ) Solid Symbols: Triaxial Extension 

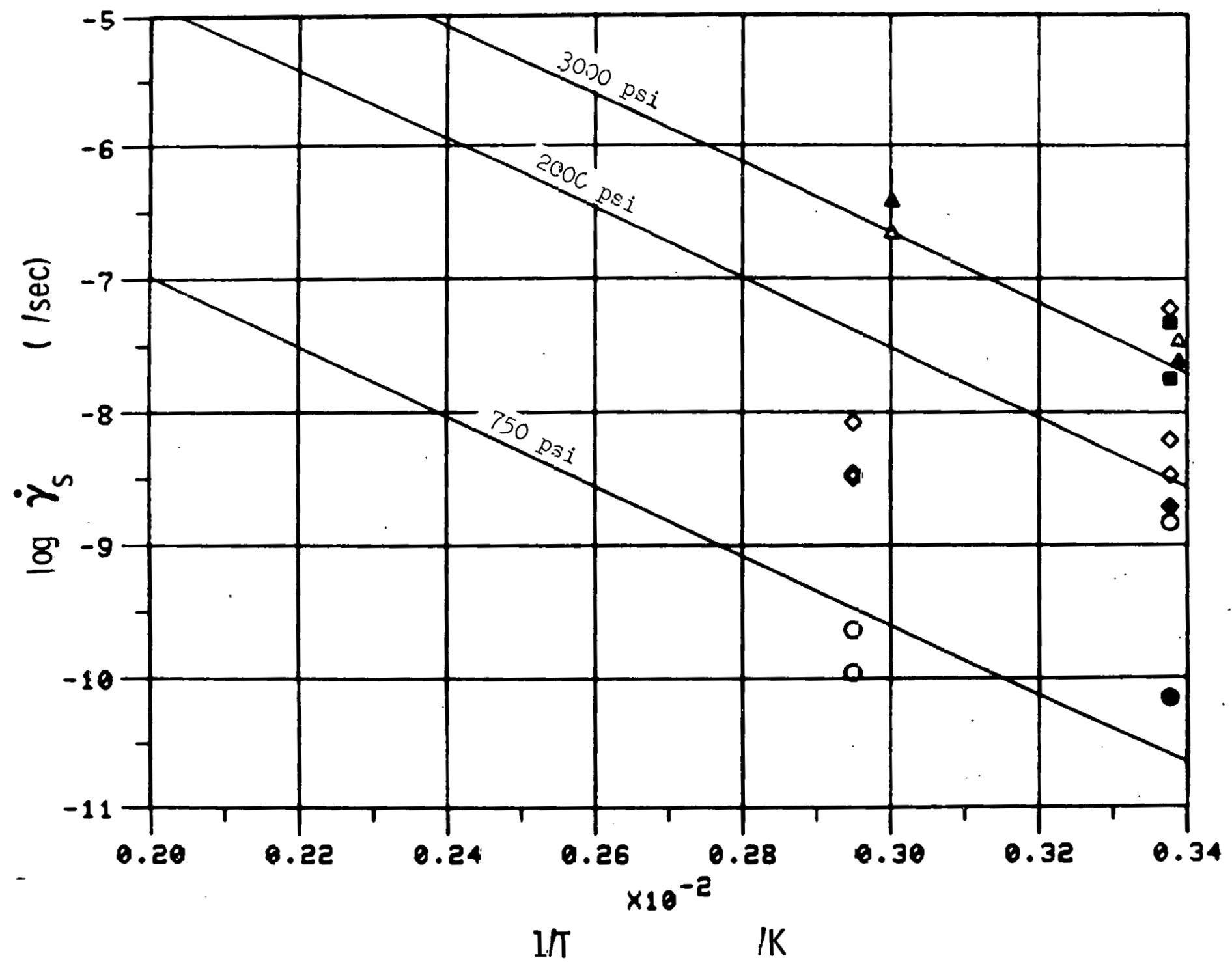

Fig. 6. Scaled Secondary Creep Fates vs Temperature for Ta:um Dome Salt 16

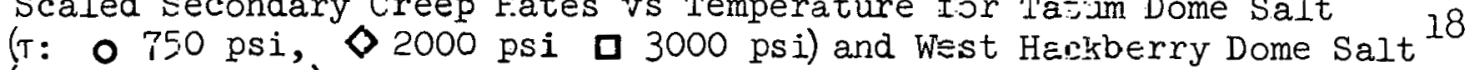

( $\tau$ : $\Delta 3000$ psi) Solid Symbols: Triaxial Extensior: 


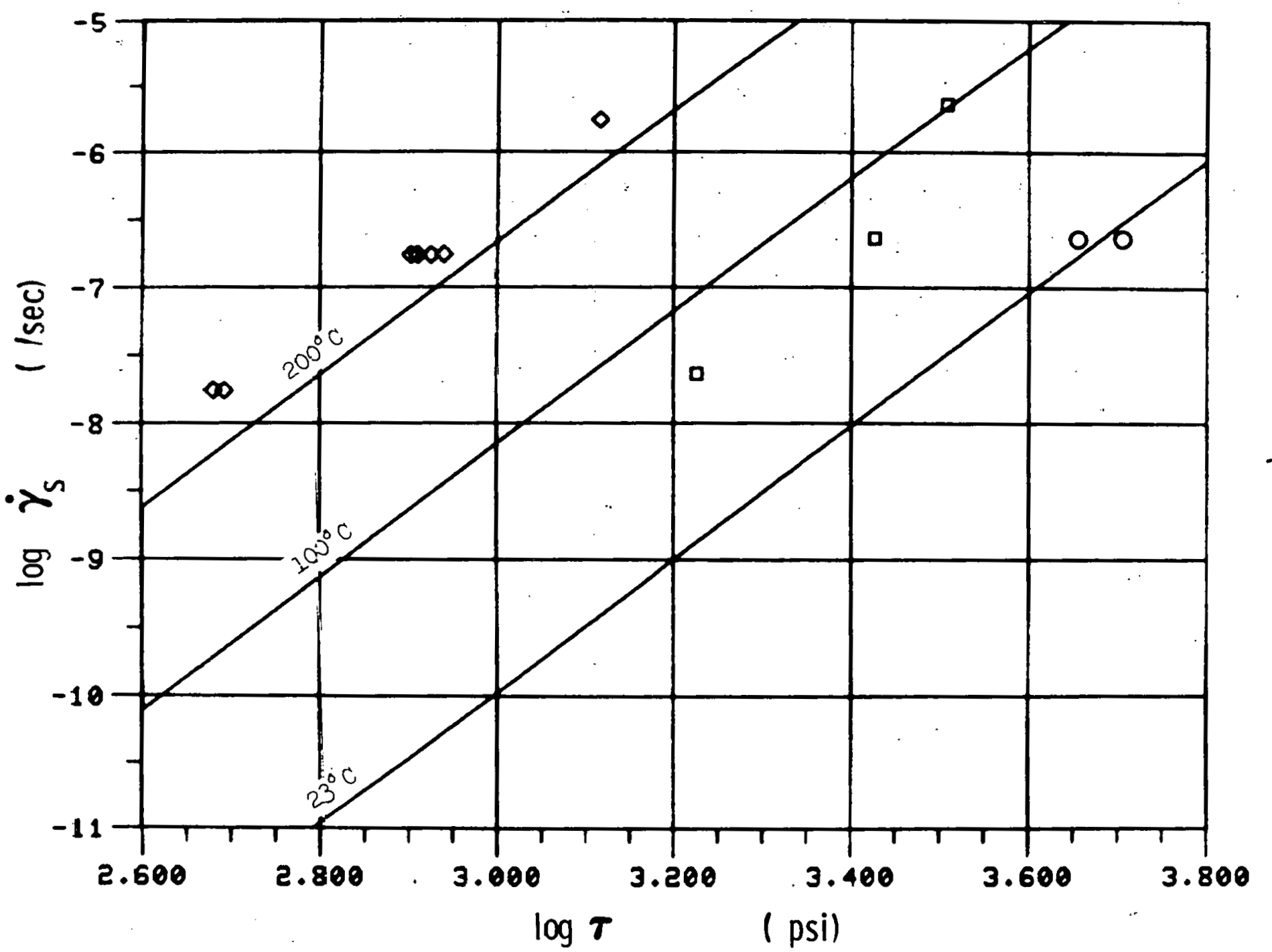

Fig. 7. Secondary Creep Rates vs Shear Stress for Polycrystalline Halite 19 $\left(\mathrm{T}: 023^{\circ} \mathrm{C}, \quad \mathrm{a} 100^{\circ} \mathrm{C}, \diamond 200^{\circ} \mathrm{C}\right.$ ) 


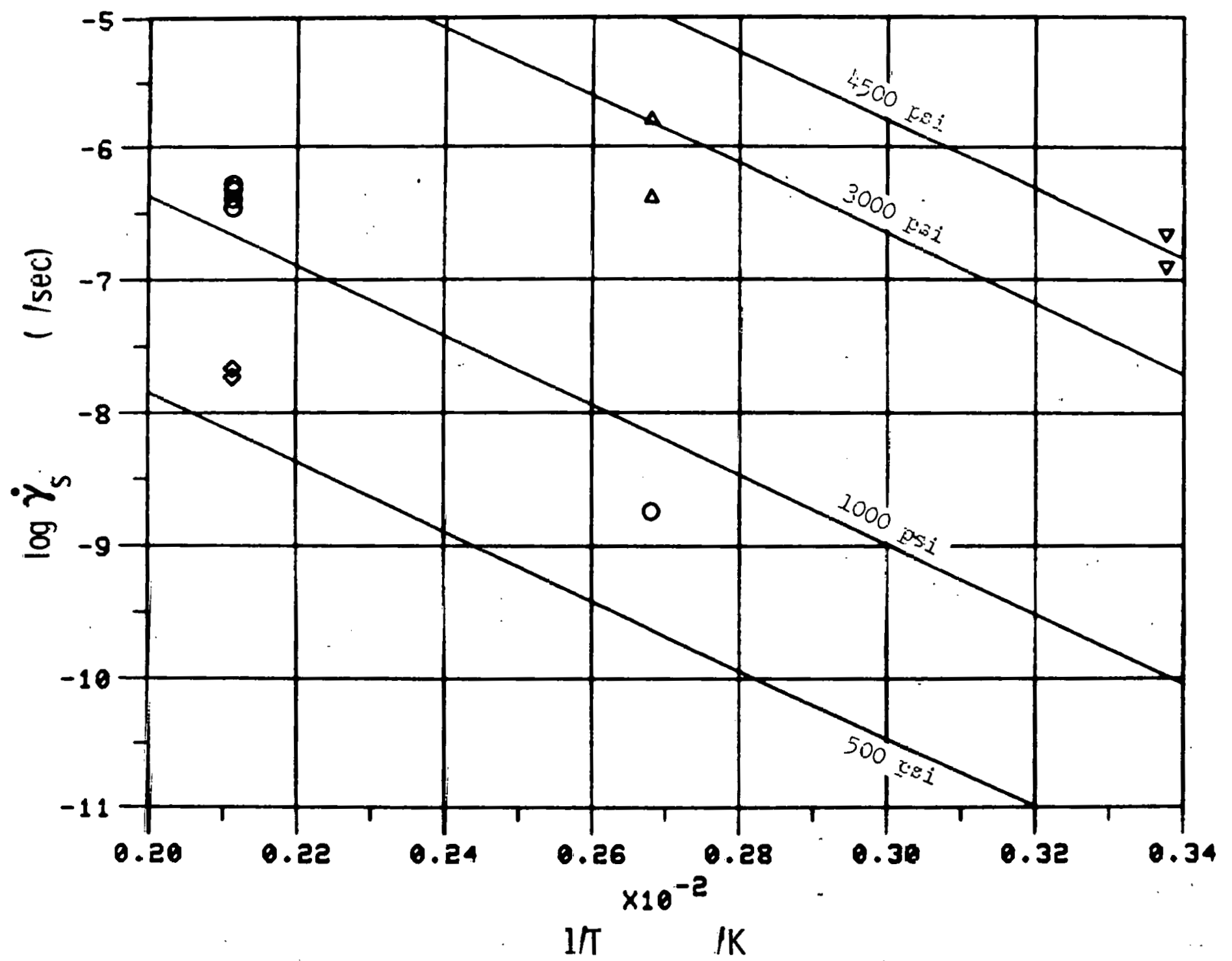

Fig. 8. Scales. Secondany Creep Fates vs Temperature for Folycrystalline Halite 19 ( $\mathrm{T}: 0.500$ psi, $0100 \mathrm{psi}, \Delta 3000$ psi, $\nabla 4500$ psi.) 
DISTRIBUTION:

U. S. Department of Energy, Headquarters Office of Nuclear Management

Washington, DC 20545

ATTN: Eugene F. Beckett (1)

Project Coordinator (WIPP)

Colin A. Heath, Director (2)

Division of Waste Isolation

Sheldon Meyers

Raymond G. Romatowski

R. Stein

Carl L. Cooley

U: S. Department of Energy

Albuquerque Operations Office

P. O. Box 5400

Albuque rque, NM 87185

ATTN: D. T. Schueler, Manager (2)

WIPP Project Office

R. Rudolph, Acting Deputy Manager WIFP Project Office

G. Dennis, Director

Public Affairs Division

S. C. Taylor, C\&TI Division

(for Public Reading Rooms)

U. S. Department of Energy

Carlsbad WIPP Project Office

Room 1.1.3, Federal Building

Carlsbad, NM 88220

U. S. Department of Finergy

c/o Battelle

Office of Nuclear Waste Isolation

505 King Avenue

Columbus, OH 43201

ATTN: Jeff 0 . Neff

Battelle Memorial Institute

Office of Nuclear Waste Isolation

505 King Avenue

Columbus, OH 43201

ATTN: Neil Carter, General Manager

$$
\begin{aligned}
& \text { R. Heineman } \\
& \text { Wayne Carbinener } \\
& \text { P. Hoffman }
\end{aligned}
$$

Westinghouse Electric. Corporation

P. 0. Box 40039

Albuquerque, NM 87196

ATTI: R. C. Mairson

D. Hulbert

Hobbs Public Library

50 iv. inip itreit.

Hobbs, NM 88248

ATTN: Ms. Marcia Lewis, Librarian
Lokesh Chaturvedi

Department of Civil Engineering

Box 3E

New Mexico State University

Las Cruces, NM 88003

Bechtel Inc.

P. O. Box 3965

San Francisco, CA 94119

ATTN: R. A. Langley

H. G. Taylor

D. L. Roberts

D. Duncan

Frank $I_{c}$. Parker, Chairman

Department of Environmental and

Water Resources Engineering

Vanderbilt University

Nashville, TN 37235

Konrad B. Krauskopf, Vice Chairman

Department of Geology

Stanford University

Stanford, CA 94305

Neville G. W. Cook Member

Dept. of Material Sciences and Engineering

University of California at Berkeley

Heart Mining Building, \#320

Berkeley, CA 94720

Merril Eisenbud, Member

Inst. of Environmental Medicine

New York University Medical Center

Box 817

Tuxedo, NY 10987

Fred M. Ernsberger, Member

Glass Reocarch Center.

PPG Industries, Inc.

Box 11472

Pittsburgh, PA 15239

Roger Kasperson, Member

Center for Technology, Environment and Development

Clark University

Worchester, MA 01610

Richard R. Par1zek, Member

Department of Hydrogeology

Pennsylvania State University

University Park, PA 16802

Thomas H. Pigford, Member

Department of Nurlear Engineering

Univesslly of Calitornia

Berkeley, CA 94720 
DISTRIBUTTUN: (Cont'd)

Roger W. Staehle, Member

Dean, Institute of Technology

University of Minnesota

Lind Hall

Minneapolis, MN 55455

John W. Winchester, Member

Department of Oceanography

Florida State University

Tallahassee, FL 32306

D'Arcy A. Shock, Consultant

233 Virginia

Fonca City, OK 74601

John T. Holloway, Executive Secretary

2101 Constitution Avenue, NW

Washington, nC. 20418

WIPP Public Reading Room

Atomic Museum, Kirtland East AFB

Albuquerque, NM 87185

ATTN: Ms. Gwynn Schreiner

WIPP Public Reading Room

Carlsbad Municipal Library

101 S. Hallagueno st.

Carlsbad, NM 88220

ATTN: Lee Hubbard, Head Librarian

Thomas Brannigan Library

$106 \mathrm{~W}$. Hadley Street

Las Cruces, NM 88001

ATIN: Don Dresp, Head Librarian

Roswell Public Library

301 N. Pennsylvania Avenue

Roswell, NM 88201

ATTN: Ms. Nancy Langston

Bruno Giletti

Department of Geological Sciences

Brown Unlver'slly

Providence, Rhode Island 02912

Raymond Siever

Departinent of' Geological siciences

Harvard University

Cambridge, Massachusetts 02138

John Handin

Center of Tectonophysics

Texas A \& M University

College Station, Texas 77840

John Lyons

Department of Darth. Scicnces

Dartmouth College

Hanover, New Hampshire 03755
George Pinder

Department of Civil Engineering

Princeton University

Princeton, New Jersey $08540^{\circ}$

New Mexico Advisory Committee on WIPP NMIMT Graduate office

Socorro, INM 87801

ATTN: Marvin $\mathrm{H}$. Wilkening, Chairman

State of New Mexico

Environmental Evaluation Group

320 Marcy Street

P.0. Bux 968

3anta Fe. MM 87\%03

A'l"I'N: Kobert H. Neill, Director (2)

IN Department of Energy \& Minerals

P.0. Dox 2770

Santa Fe, NM 87501

ATTN: Larry Kehoe, Secretary

Kasey LaPlante; Librarian

J. E. Magruder

Sandia Carlsbad Representative

401 North Canal Street

Carlsbad, NM 88220

Brookhaven National Laboratory

Associated Universities, Inc.

Upton, Long Island, New York 11973

ATTN: Cal Brewster, Bldg. 830

Paul W. Levy, Physics Dept.

D'Appólonia Consulting Engineers, Inc. 2350 Alamo, S.E.

Suite 103

Albuquerque, NM 87106

ATTN: A. K. Kuhn

D. E. Maxwell

Science Applications, Inc.

2450 Washington Avenue, Euitc 120

San Leandro, CA 94577

$\mathrm{RE} / \mathrm{SPEC}$ Inc.

F.U. Box 725

Rapid City, SD 57701

ATTN: Dr. P. Gnirk

F. Hansen

Billy J. Thorne, Vice President

Civil Systems Inc.

2201 San Pedro NE, Suite 214

Albuquerque, NM 87110

Dr. Paul R. Dawson

254 Upson Hall

Dept. Mech. \& Aerospace Engr.

Cornell University

Ithaca, NY 14853 
Prof. M. F. Ashby

University of Cambridge

University Engineering Department

Trumpington Street

Cambridge $\mathrm{CBI}$ 2PX ENGLAND

Department of Materials Science and Engineering

Stanford University

Stanford, CA 94305

ATTN: Prof. W. D. Nix

Prof. Oleg Sherby

Hugh C. Heard L340

Lawrence Livermore Laboratory

University of California

P. 0. Box 808

Livermore, CA 94550

R. L. Thoms

Louisiana State University

Center for Environmental Studies

Baton Rouge, LA 70504

$\begin{array}{ll}1100 & \text { C. D. Broyles } \\ 1110 & \text { J. D. Plimpton } \\ 1111 & \text { J. R. Banister } \\ 1112 & \text { F. F. Dean } \\ 1112 & \text { C. R. Mehl } \\ 1112 & \text { J. J. Hohlfelder } \\ 1112 & \text { R. I. Ewing } \\ 1116 & \text { C. W. Cook } \\ 1116 & \text { E. S. Ames } \\ 1120 & \text { T. L. Pace } \\ 1121 & \text { R. L. Rutter } \\ 1125 & \text { G. L. Ogle } \\ 1125 & \text { A. C. Arthur } \\ 1125 & \text { J. T. McIlmoyle } \\ 1130 & \text { H. E. Viney } \\ 1133 & \text { R. D. Statler } \\ 1133 & \text { C. W. Gulick } \\ 1520 & \text { T. J. Hoban } \\ 3310 & \text { W. D. Burlett } \\ 3311 & \text { D. R. Parker, Attn: L. W. Brewer } \\ 3312 & \text { G. E. Tucker, Attn: J. H. Metcalf } \\ 3313 & \text { A. L. Stanley } \\ 4500 & \text { E. H. Beckner } \\ 4510 & \text { W. D. Weart } \\ 4511 & \text { W. D. Weart (Actg.) } \\ 4511 & \text { G. E. Barr } \\ 4511 & \text { I. W. Powers } \\ 4512 & \text { T. O. Hunter (5) } \\ 4512 & \text { C. L. Christensen } \\ 4512 & \text { M. A. Molecke } \\ 4514 & \text { M. L. Merritt } \\ 4514 & \text { F. W. Bingham } \\ 4530 & \text { R. W. Lynch } \\ 4537 & \text { L. D. Tyler } \\ 4538 & \text { R. C. Lincoln } \\ 4540 & \text { M. L. Kramm } \\ 4341 & \text { L. W. Scully } \\ \end{array}$

4541 H. C. Shefelbine

4541 W. E. Wowak

4541 A. W. Dennis

4542 J. W. McKiernan

4542 J. T. Henderson

4543 J. R. Tillerson

4543 R. R. Beasley

4732 D. T. Murison

4738 J. R. Wayland

5112 P. S. Peercy

5112 G. W. Arnold

5500 O. E. Jones

5510 D. B. Hayes

5511 J. W. Nunziato

5511 G. R. Hadley

5520 T. B. Lane

5521 S. W. Key

5521 R. D. Krieg

5521 C. M. Stone

5522 S. E. Benzley

5530 W. Herrmann (10)

5531 L. D. Berthoif

5531 S. E. Montgomery

5531 W. T. Brown

5531 P. F. Chavez

5531 H. S. Lauscn

5532 B. M. Butcher

5532 L. S. Costin

5532 W. A. Olsson

5532 L. W. Teufel

5532 W. R. Wawersik (10)

5812 C. J. Northrup

5812 R. G. Dosch

5812 B. T. Kenna

5812 E. J. Nowak

5830 M. J. Davis

5840 N. J. Magnani

$5841 \mathrm{~J}$. W. Braithwaite

8316 J. R. Springam

8266 Tech Library

3141 Tech Library

31.51 Teoh Writing (3)

For DOE/TIC (Unlimited Release)

DOE/TIC (25)

(R. P. Campbell, 3154-3) 
